\title{
Factors Affecting the Levels of Open Defecation in Cibaduyut, Bandung, Indonesia
}

\section{Budiman Budiman*and Selvia Indiyani}

Public Health Departement, Sekolah Tinggi Ilmu Kesehatan Jenderal Achmad Yani, Cimahi, Indonesia

\section{ORCID}

Budiman Budiman: https://orcid.org/0000-0003-3958-830X

Corresponding Author: Budiman

Budiman; email:

budiman_1974@yahoo.com

Published: 7 February 2022

Publishing services provided by

Knowledge E

(c) Budiman Budiman and Selvia Indiyani. This article is distributed under the terms of the

commons Attribution License,

which permits unrestricted use and redistribution provided that the original author and source are credited.

Selection and Peer-review under the responsibility of the IVCN Conference Committee.

G OPEN ACCESS
Abstract. An area is categorized as Open Defecation Free (ODF) when the community has carried out total sanitation practices and does not defecate openly. In Indonesia, more than 58 million people still practice open defecation; in the city of Bandung only 17 of the 151 sub-districts have 100\% ODF categorization and Cibaduyut sub-district only has $26 \%$ ODF. This study aimed to determine the factors associated with the levels of open defecation in Cibaduyut Village, Bandung City. This was a cross-sectional study. The sample consisted of 92 heads of families who live in Cibaduyut Village, and the sampling technique used was stratified random sampling. Data were collected by means of interviews and a questionnaire. Data analysis involved multivariate analysis to understand the determinants of the levels of open defecation using the KMO \& Barlett's test. The results showed that there was a significant relationship between knowledge, attitudes, income, latrine ownership, and social interaction ( $p$-value $=0.0001$ ), and the KMO \& Barlett's test value was 0.508. However, after the anti-image matrices test, it was deemed that the ownership of the latrine variable could not be analyzed further (MSA value $0.460<0.50$ ). The most influentual factors were community factors (attitudes and social interaction) and individual factors (knowledge and income). It is recommended that a communal septic tank is made so that people do not defecate carelessly and there is a place for processing feces. The puskesmas and the health office need to increase their active role in providing counseling and empowering the community to understand the importance of having healthy latrines, so that they can and are able to build independent and communal septic tanks.

Keywords: community, individual, ODF, cross-sectional, factor analysis

\section{Pendahuluan}

Sanitation is one component of environmental health, sanitation is one of the health efforts by maintaining and protecting the environment from its subjects [1]. Sanitation is also goal number 6 in the Sustainable Development Goals (SDGs) era, namely to ensure universal access to clean water and sanitation for the community. The realization of these efforts is carried out through the Community-Led Total Sanitation program (CLTS) [2]. Community-Led Total Sanitation (CLTS) is a government program in order to strengthen efforts to cultivate a clean and healthy life, prevent the spread of environmental-based 
diseases, increase community capacity, and implement the government's commitment to improve access to drinking water and sustainable basic sanitation [3].

In the 5 (five) CLTS pillars, Stop Open Defecation or Open Defecation Free (ODF) is the first pillar, which is a condition when every individual in the community does not open defecation. ODF behavior is followed by the use of sanitation facilities whose conditions meet health standards and requirements in the form of healthy latrines. Stop Open Defecation is a condition when every individual in a community no longer performs open defecation behavior that has the potential to spread disease. [3].

The first pillar of CLTS, namely Stop Open Defecation, is an effort to break the chain of contamination of human waste to raw drinking water, food, and others. [4]. This contamination can harm humans, because human waste has several dangerous components such as: microbes, organic matter, worm eggs, and nutrients [5]. The success of the CLTS program in the community can be measured by the achievement of the village indicators implementing CLTS and the Village Stop Open Defecation Free (ODF).

Open Defecation Free is a condition where the community has carried out total sanitation by not defecating openly. A village can be said to be ODF if all of its residents have access to healthy latrines such as septic tanks [6]. It is estimated that 673 million people in the world still practice open defecation. Meanwhile, in Indonesia, more than 58 million people still practice open defecation [7].

According to the [8], there were 16194 villages verified by ODF from 83,805 or $20.04 \%$ of the total villages. The number of villages/kelurahan as many as 2337 already has a sanitation coverage of more than $99 \%$ but has not yet reached $100 \%$. A total of 3354 villages/kelurahan have sanitation coverage of more than or equal to $97.5 \%$ but not $100 \%$. A total of 4562 villages/kelurahan have reached ODF status but have not been verified [9]. In 2018, as many as 103 (68.21\%) urban villages have implemented CLTS from 151 urban villages in Bandung City [10].

There are 151 urban villages in Bandung, but there are only 17 100\% Open Defection Free (ODF) villages, namely Rancanumpang Village (2015), Cihapit Village, Citarum Village, Ciateul Village, Paledang Village, Manjahlega Village (2017), Antapani Village Central (2019), Cipadung Kidul Village, Rancabolang Village, Mekarmulya Village, Cimincrang Village, Cisaranten Kidul Village, Cisaranten Kulon Village, Derwati Village, Cipamokolan Village, Mekarjaya Village, and Sarijadi Village (2020). Thus, in the city of Bandung there are already 2 ODF Districts, namely Gedebage District and Rancasari District [11]. 
Monitoring and Evaluation of CLTS as many as 12847 or 64.69 families in Bojongloa Kidul District are still carrying out ODF [12]. Based on the results of an introspective survey at the Cibaduyut Kidul Public Health Center in 2021, it was found that in Cibaduyut Village as much as $74 \%$ still carry out open defecation, ODF data in Cibaduyut Village $26 \%$ [13]. The low number of ODF in Cibaduyut Village is due to several factors such as knowledge, attitudes, income, latrine ownership, and social interaction.

Knowledge is a very important domain in shaping one's behavior, the higher one's knowledge about the consequences of a disease, the higher the prevention efforts that need to be done [14]. The good attitude of the head of the family is expected to change the practice of open defecation in the family. A good attitude if supported by supporting facilities and infrastructure will result in defecation in the latrine using a septic tank [15]. One of the reasons people still carry out open defecation is because the community cannot afford to buy latrines [16].

A person who can behave in a healthy manner needs to be supported by facilities and infrastructure or health facilities such as clean water, garbage disposal sites, and excreta disposal sites [17]. People's behavior with open defecation is more commonly found in people with less social support, of which there are still few who have ever reprimanded other people who defecate openly [18]. From this description, the researcher is interested in conducting research on "Analysis of Factors Affecting the Low ODF Number in Cibaduyut Village, Bandung City in 2021".

\section{Methods}

This study uses a cross sectional study design which was carried out in Cibaduyut Village, Bandung City in July-August 2021. The population used was all heads of families in Cibaduyut Village. The sample used is 92 heads of families. Respondents who filled out the questionnaire were ensured that their confidentiality was maintained. The respondent used is a family head who has income and still carries out open defecation. The sampling technique used stratified random sampling technique. The tests carried out in this study used orthogonal factor analysis.

\section{Results}

This study uses orthogonal factor analysis using 92 samples and obtained a KMO MSA value of 0.508 , this value indicates that there is a relationship between variables, the 
TABLE 1

\begin{tabular}{cc|l} 
& Test & Result \\
& KMO MSA & 0,508 \\
Tes Barlett & Chi Square & 68,269 \\
& df & 10 \\
& sig & 0,000
\end{tabular}

TABLE 2

$\begin{array}{ll}\text { Anti-image correlation } & \text { Result } \\ \text { Z score Knowledge } & 0,521 \\ \text { Z score Revenue } & 0,601 \\ \text { Z scoreAttitude } & 0,505 \\ \text { ZscoreLatrine Ownership } & 0,460 \\ \text { ZscoreSocial Interaction } & 0,507\end{array}$

variables can be analyzed further and the number of samples meets the requirements for analysis to the next stage.

In the second test, which is to see the value of Anti-image Matrices for each variable, but regarding the ownership of the latrine, it is 0.460 where the MSA value is $<0.5$ which if there is a variable value less than the minimum limit, the variable must be removed or discarded.

Because there are variables that need to be removed, it is tested again without using the latrine ownership variable and the KMO MSA value increases to 0.511 and the value of Anti-image Matrices also increases.

Knowledge variable is 0.613 , it means that $61.3 \%$ of the variance of the knowledge variable can be explained by the formed factor. The income variable is 0.501 it means that $50.1 \%$ of the variance of the income variable can be explained by the formed factor. Attitude variable is 0.855 , it is $85.5 \%$ variance of the attitude variable which can be explained by the formed factors, and finally the Social Interaction Variable is 0.848 , it is $84.8 \%$ variance from the social interaction variable which can be explained by the formed factors.

TABLE 3

\begin{tabular}{l|l} 
Anti-image correlation & Result \\
Z score Knowledge & 0,553 \\
Z score Revenue & 0,640 \\
Z scoreAttitude & 0,507 \\
ZscoreLatrine Ownership & 0,507
\end{tabular}


TABLE 4

\begin{tabular}{l|l} 
Communalities Test & Extraction \\
\hline ZscoreKnowledge & 0,613 \\
\hline ZscoreRevenue & 0,501 \\
ZscoreAttitude & 0,855 \\
\hline ZscoreSocial Interaction & 0,848
\end{tabular}

TABLE 5

$\begin{array}{ll}\text { Component } & \text { Eigen values } \\ 1 & 1,761 \\ 2 & 1,055 \\ 3 & 0,894 \\ 4 & 0,289\end{array}$

From the table below, it can be seen that there are only two factors that form eigenvalues, because the 1st and 2nd factors have eigenvalues above 1.

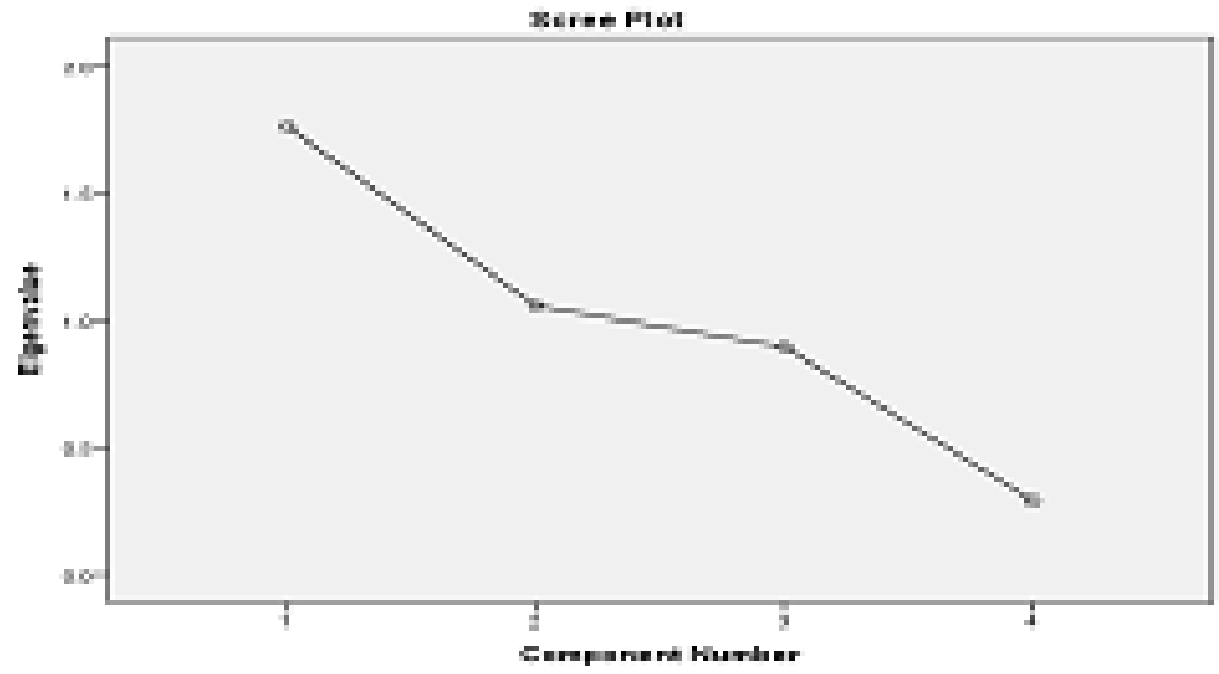

From the Scree Plot image, the eigenvalues 1 are in component 2, so it can be concluded that in this factor analysis there are 2 factors formed.

After it is known that there are two factors which are the most optimal number, then this table shows the distribution of the four variables on the two existing factors. The

TABLE 6

\begin{tabular}{llc} 
Variable & \multicolumn{1}{c}{ Component } \\
\hline ZscoreKnowledge & 1 & 2 \\
\hline ZscoreRevenue & 0,199 & $-0,757$ \\
\hline ZscoreAttitude & $-0,302$ & 0,640 \\
ZscoreSocial Interaction & 0,905 & 0,190 \\
\hline
\end{tabular}


TABLE 7

Variable
ZscoreKnowledge
ZscoreRevenue
ZscoreAttitude
ZscoreSocial Interaction

$\begin{array}{lc} & \text { Component } \\ 1 & 2 \\ -0,016 & 0,783 \\ -0,116 & -0,698 \\ 0,922 & 0,065 \\ 0,919 & 0,062\end{array}$

numbers contained in the table are factor loadings or the correlation between a variable and factor 1 or 2 . Component of factor 1: Attitude and Social Interaction and Component of factor 2: Knowledge and Income. However, for the knowledge variable there is no significant difference between the two loading factors, so that the variable cannot be entered directly into the two component factors and a rotation process will be carried out.

After being rotated, there are still two components, the table shows a clearer and more significant distribution of the variables. It can be seen that the small loadings factor is getting smaller and the large one is getting bigger. Component 1 is attitude and social interaction, component 2 is knowledge and income.

Axis $X(C o m p o n e n t / F a c t o r ~ 1):$ Attitudes and Social Interaction and Axis $Y$ (Component/Factor 2) : Knowledge and Knowledge. Factor/Component 1 is named Community Factor and Factor/Component 2 is named Individual Factor.

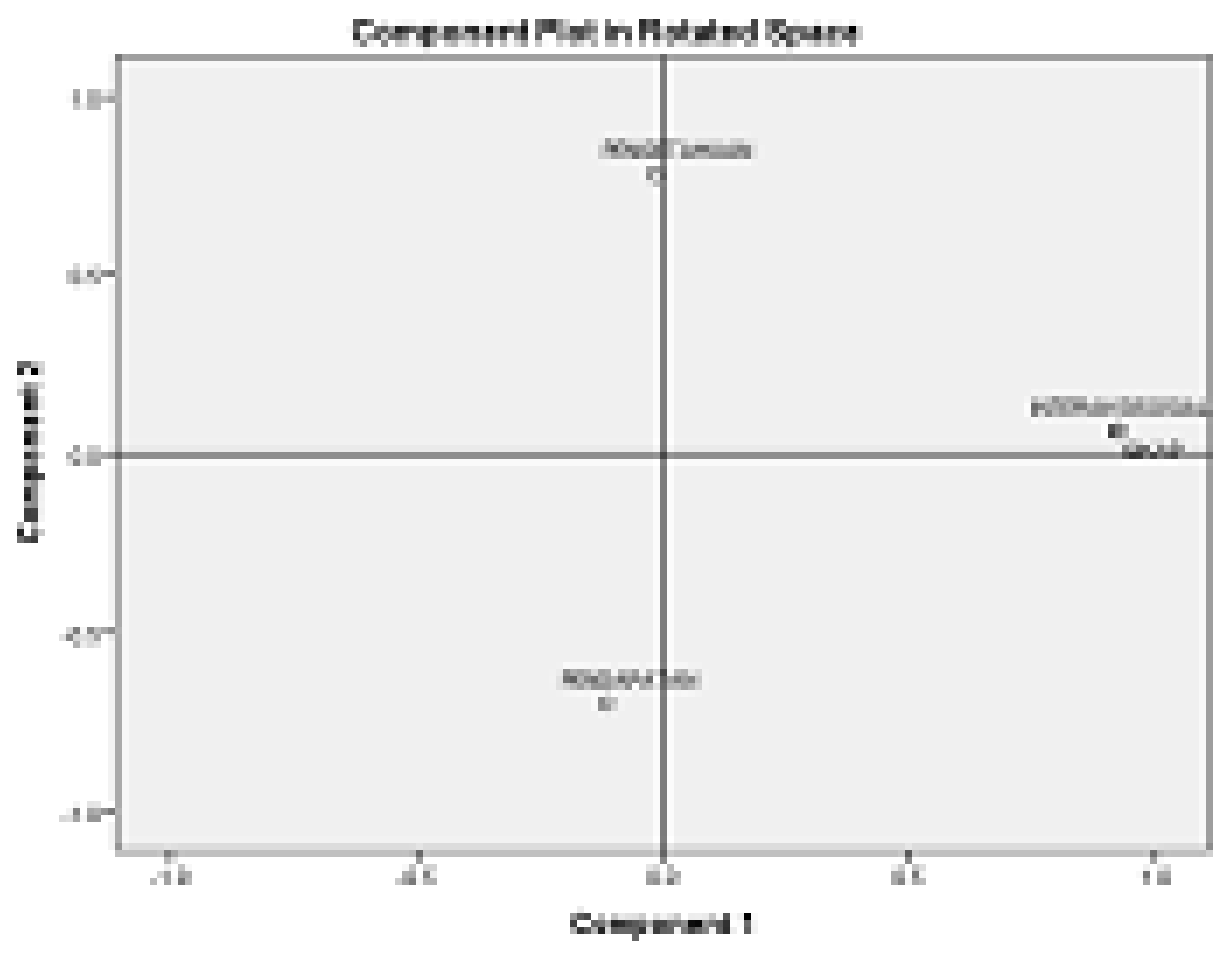




\section{Discusion}

Knowledge is a very important domain in shaping one's behavior, the higher one's knowledge about the consequences of a disease, the higher the prevention efforts that need to be done [14]. One of the factors that affect a person's knowledge is education [19]. Education is very important in developing human resources for environmental sanitation needs, someone who has low education may not have a healthy latrine due to lack of literacy about it [14].

The higher one's education, the more rational one's The research conducted is in accordance with previous research, which is that there is a significant relationship with the behavior of people who defecate openly mindset in good health and sanitation [20]. The research conducted is in accordance with previous research, which is that there is a significant relationship with the behavior of people who defecate openly [21]. People's knowledge is low, the potential for open defecation is getting bigger [22]. People don't open defecation because they have good knowledge about defecating in healthy latrines [23].

The results showed that there was a significant relationship between knowledge and other variables and was strongly correlated, this was shown in the value of the KMO and Barlett's test results above 0.5 which if the $p$ value $<\alpha(0.05)$ then there was a significant relationship between independent variable, the sample is adequate for further analysis. Knowledge factor is included in factor 2 or individual factors Knowledge or cognitive is a very important domain for the formation of one's actions [19]. The determinants of a person's behavior depend on his knowledge, the better a person's knowledge, the more positive his behavior [24]

is not necessarily an action or activity, but is a predisposition to an action or behavior. Attitude is a closed reaction. but is a predisposition to an action or behavior. Attitude is a closed reaction. Attitude is a reaction to objects in a certain environment as an appreciation of the object [19]. The good attitude of the head of the family is expected to change the practice of open defecation in the family. A good attitude if supported by supporting facilities and infrastructure will result in defecation in the latrine using a septic tank [15].

The good attitude of the head of the family is expected to change the practice of open defecation in the family. A good attitude if supported by supporting facilities and infrastructure will result in an action, in this case is a good practice of defecation, namely defecating in a latrine with a septic tank. [25] 
The behavior of a person or society is determined by one's attitude, the worse one's attitude, the less likely one is to have a healthy latrine [26]. This research is in accordance with previous research, namely the better the attitude of the head of the family, the less open defecation [23]. Attitude has a significant relationship with open defecation behavior, a bad attitude has the potential to endanger personal health and the environment [27].

The results showed that the KMO and Barlett's test values were above 0.5, which if $p$ value $<\alpha(0.05)$ then there was a significant relationship between the independent variables, the sample was adequate for further analysis. which means that there is a significant relationship between the attitude of the head of the family towards other independent variables. Attitudes are included in component 1 or community factors. Positive attitudes and habits of the community, the higher the ODF number, attitudes greatly affect people's habits in defecating openly [24].

The ability of a family head to finance the construction to build a healthy WC/latrine and the materials to make the building available locally, can be assessed as factors that support a family head to want to build or have a healthy latrine. [19]. One of the reasons people still carry out open defecation is because the community cannot afford to buy latrines [16]. Low income makes a person have a bad attitude about having a healthy latrine, family income is a supporter of a very basic need in making healthy latrines, the higher a person's income level can affect the assurance of behavior and concern for public health Income is an important predictor of latrine ownership [28].

Low income is associated with open defecation, income levels affect the availability of healthy latrine facilities and infrastructure, because making healthy latrines requires a lot of money. [29]. This is in line with the research conducted, namely that there is a relationship between family income and defecation behavior [30]. This is in accordance with the results of the study that there is a relationship between income and open defecation behavior [15]. In accordance with the research conducted, there is a relationship between income and open defecation behavior [31].

The results of the study show that there is a significant relationship between income and other independent variables, this is shown in the value of the KMO test and Barlett's test above 0.5 which if $p$ value $<\alpha(0.05)$ then there is a significant relationship between the independent variables. , the sample is adequate for further analysis. Income is included in component 2 or individual factors. Low income levels do not participate in maintaining environmental health, so it is very influential in the ownership of healthy latrines, where healthy latrines are an indicator to increase the number of ODF [32]. 
A latrine is a room that has a human waste disposal facility equipped with a sewage and water collection unit to clean it [33]. A healthy latrine is an effective faecal disposal facility to break the chain of disease transmission. A healthy latrine is a faecal disposal facility that does not pollute water, surface soil, is free of insects, does not cause odor and is comfortable, safe, easy to clean and does not cause disturbance to the wearer, does not cause disrespectful views. [16].

Open defecation and not using healthy latrines are one of the habits of individuals who imitate other individuals, many people defecate openly because of low ownership of healthy latrines, this is in accordance with research that has been done [34]. A person who can behave in a healthy manner needs to be supported by facilities and infrastructure or health facilities such as clean water, garbage disposal sites, and excreta disposal sites. [17].

Respondents who have poor behavior are more likely to be heads of families whose facilities are incomplete or have latrines but the latrines are not healthy latrines. [35]. Ownership of a healthy latrine is strongly influenced by, attitudes, income, habits, of each individual [36]. However, ownership of unhealthy latrines is also not always influenced by lack of knowledge, even good knowledge can have unhealthy latrines. [37].

The results of the study indicate that there is a significant relationship between latrine ownership and other independent variables, this is shown in the value of the KMO test and Barlett's test above 0.5 which if $p$ value $<\alpha(0.05)$ then there is a significant relationship between variables. independent, the sample is adequate for further analysis. After factor analysis, the latrine ownership variable cannot be further processed to determine the most determinant factor for the low ODF rate in Cibaduyut Village, however, latrine ownership is one of the factors that has a significant relationship to the low ODF rate.

Social interaction is a reciprocal relationship between individuals with other individuals, individuals with groups, and groups with others, where these relationships affect, change, or improve the behavior of other individuals or vice versa. [38]. Social interaction is one dimension of social support [39]. People's behavior with open defecation is more commonly found in people with less social support, of which there are still few who have ever reprimanded other people who defecate openly [18].

Someone who is in a social environment will affect a behavior. The social environment is influenced by social support such as (family, community, and religious leaders), the success of Open Defecation Free is due to good social activities such as trusted leaders, mutual cooperation, and togetherness. (Chitra \& Naraha, 2019). This is in accordance 
with research that there is a relationship between the social environment and open defecation behavior [23]

The results of the study show that there is a significant relationship between social interaction and other independent variables, this is shown in the value of the KMO test results and Barlett's test above 0.5 which if the $p$ value $<\alpha(0.05)$. Social interaction is included in component 1 or community factors. Open defecation behavior is still widely practiced due to low motivation that needs to be improved, because motivation is one of the obstacles in realizing Open Defecation Free [40].

\section{Conclussion}

Knowledge has an influence on the low number of ODF, the lower the knowledge of the head of the family, the lower the number of defecation free will also be lower in Cibaduyut Village.

Attitudes have an influence on the low number of ODF, the worse the attitude of the head of the family, the lower the number of ODF in Cibaduyut Village. Income has an influence on the low ODF number, the greater the income earned by the head of the family, the lower the ODF number in Cibaduyut Village

Toilet ownership has an influence on the low number of ODF, from the analysis test results obtained latrine ownership variables with other independent variables and have a strong correlation, with the KMO Barlett's test value of 0.511 , and the MSA value of 0.460 so it can be concluded that the latrine ownership variable is significant but because MSA value $<0.5$ then the latrine ownership variable cannot be analyzed further, because people in Cibaduyut Village generally have latrines but do not meet the criteria for healthy latrines, from the results of the questionnaire obtained and the answers to most respondents who do not meet the requirements for healthy latrines, namely the latrines are still there are animals that can spread the chain of disease (rats, cockroaches and insects) and the latrines owned by the respondent still contaminate the soil around their house.

Social interaction has an influence on the low number of ODF, the less social interaction that is carried out by the head of the family, the lower the number of ODF in Cibaduyut Kidul Village. The most dominant factors related to the low number of ODF in Cibaduyut Village are Community Factors (Attitudes and Social Interaction and Attitudes) and Individual Factors (Knowledge and Income) so that these two factors are factors that cause why the ODF rate in Cibaduyut Village is still low. 


\section{References}

[1] Sakula MA, Retno W. Food sanitation hygiene textbook. Ponorogo: Uwais Insppirasi Indonesia; 2018.

[2] Ministry of Health of Republic of Indonesia. Efforts to realize human development goals through successful sanitation programs.

[3] Permenkes RI No 3 Tahun 2014 about community based total sanitation.

[4] Rumajar PD, Katiandagho D, Robert D. Analysis of success level of community-leed total sanitation program (clts) in the work area of manganitu puskesmas, Lepl regency. Sangihe (Study in taloarane village I). Jurnal Kesehatan Lingkungan. 2019;9:10-19.

[5] Indasah K. Environmental health sanitation, environmental health and K3. Yogyakarta: Deepublish Publisher; 2017.

[6] Ika PHS, Mursid R, Nurjazuli N. Relationship of knowledge, attitude of chapters, and ownership of septic tanks with ODF (Open defecation free) status in Candisari District, Semarang City. Jurnal Kesehatan Masyarakat. 2018;6:143-149.

[7] Yulyani V, Febriani CA, Shaharudin MS, et al. Patterns and determinants of open defecation among urban people. Kesmas. 2021;16:45-50.

[8] Ministry of Health of Republic of Indonesia. Indonesian household sanitation coverage. Ministry of Health of Republic of Indonesia; 2018. Available from: http://stbm.kemkes.go.id/review_stbm/findings.html

[9] Ministry of Health of Republic of Indonesia. Cleaner, healthier CLTS.

[10] Department BH. Health Profil.

[11] Bandung public relation of. In 2020 Bandung city targets 100\% ODF.

[12] Ministry of Health of Republic of Indonesia. CLTS data.

[13] Laporan survey mawas diri puskesmas Cibaduyut Kidul. 2020.

[14] Fera N, Rizka A. determinants of healthy latrine ownership in Sukomulyo Martapura Village, Palembang. Jurnal Ilmu Kesehatan. 2017;107:107-116.

[15] Regita DP, Joko T, Rahardjo M. Relationship between individual social characteristics, knowledge, attitudes, and availability of sanitation facilities with defecation practices in Taman Subdistrict, Pemalang Regency. Epub ahead of print 2020. DOI: 10.14710/mkmi.19.2.141-146

[16] Mukmin S, Pancawati MS, Al E. Latrine credit success tips. Ministry of villages PDT and transmigration. Kementerian Desa PDT dan Transmigrasi; 2020.

[17] Qudsiyah WA. Factors associated with high open defecation (OD) rates in Jember Regency (Study in Sumber Kalong Village, Kalisat District). Jurnal Pustaka Kesehatan. 2015;3:362-369. 
[18] Aulia A. Factors related to open defecation (babs) behavior in Kamal Village, Larangan District. Jurnal Kesehatan Masyarakat. 2020;9:166-175.

[19] Notoatmodjo N. Health research methods. Jakarta: Rineka Cipta; 2018.

[20] Busienei PJ, Ogendi GM, Mokua MA. Open defecation practices in Lodwar, Kenya: A mixed-methods research. Environmental health insights. 2019;13. DOI: 10.1177/1178630219828370

[21] Agustiyaningsih T, Kurnia AD, Larasati RY. Relationship of knowledge about healthy latrine and physical environment with indiscriminate defecation behavior. Dunia Keperawatan J Keperawatan dan Kesehat. 2020;8:130.

[22] Warlenda SV, RAdlifa RAD, Sari NP, et al. Relationship of basic sanitation, knowledge, behavior and income to open defecation habits in Laksamana Village, Dumai health center working area in 2020. 2021;11:6.

[23] Shaluhiyah Z, Widagdo L, Wijayanti A. Factors related to defecation in the latrine in Gunungsari Village, Pulosari District, Pemalang Regency. Jurnal Kesehatan Masyarakay. 2016;4:450-460.

[24] Marwanto A, Netrianis N, Mualim M. The relationship between knowledge levels and attitudes with the implementation of community-leed total sanitation (CLTS) first pillar in the Uptd Work Area of Ratu Agung Health Center, Pematang Village, Bengkulu City Governor. Journal of Nursing and Public Health. 2019;7:1-6.

[25] Paramita RD, Sulistyorin L. The attitude of the head of the family affects the low use of toilets in RW 02 Gempolklutuk Village, Tarik District, Sidoarjo Regency. Jurnal Kesehatan Lingkungan. 2015;8:184-194.

[26] Suryani D, Hendriyadhi S, Suyitno S, et al. Ownership of healthy latrine in coastal communities, Binjai Village, West Bunguran District, Natuna Regency. Jurnal Dunia Kesmas. 2020;9:346-354.

[27] Astuti NY, Kasmini OW, Indriyanti DR. The effectiveness of KATAJAGA health education on the changes of knowledge, attitudes, and behavior of defecation of community in Tambakromo Bojonegoro. Public Health Perspective Journal. 2021. Vol 6, No 2.

[28] Harter M, Mosch S, Mosler HJ. How does community-led total sanitation (CLTS) affect latrine ownership? A quantitative case study from Mozambique. BMC Public Health. 2018;18:1-10.

[29] Paladiang R, Haryanto J, Marah HEM. Determinants of open defecation behavior (BABS) in Kiritana Village, Kambera District. Indonesian Journal of Community Health Nursing. 2020;5:33. 
[30] Nurfita Sari, A. Relationship of knowledge level, attitude and income level with family defecation behavior in Kerjokidul Village, Ngadirojo District, Wonogiri Regency. Doctoral dissertation, Universitas Muhammadiyah Surakarta. 2016.

[31] Hayana H, Marlina H, Kurnia A. relationship between individual characteristics and social environment to behavior open defecation. Jurnal Kesehatan Komunitas. 2018;4:8-15.

[32] Wijayanti W, Maulana M. Faktor-faktor yang berhubungan dengan kepemilikanfactors associated with ownership of healthy latrine in the hamlet of responsibilities, Karangpatihan Village, Balong District, Ponorogo Regency. Fak Kesehat Masy Univ Ahmad Dahlan. 2019;1:1-15.

[33] Siregar AP. Advanced health promotion in theory and application. Jakarta: Prenada Media; 2020.

[34] Kurniawati RD, Saleha AM. Analysis of knowledge, attitudes, and roles of healthcare workers with participation in the prevention of open defecation. Jurnal IImu Kesehatan Masyarakat. 2020;9:3-11.

[35] Nina N. The relationship of knowledge, facilities, and socio-economic with the habit of open defecation (BABS) in the community. Jurnal IImu Kesehatan Masyarakat. 2019;8:30-39.

[36] Risnawati, R., Lilimantik, E., Mahreda, E. S., \& Mahyudin, P. Factors affecting ownership of healthy toilets in the UPTD territory of Bentot Health Center, Patangkep Tutui District, East Barito Regency, Central Kalimantan. Jurnal Akrab Juara. 2020;5(3), 223-239.

[37] Pulungan AA, Wirsal Hasan N. Factors associated with family latrine ownership in Sipange Julu Village, Sayur Matinggi District, South Tapanuli Regency in 2013. Sereal Untuk. 2018;51:51.

[38] Ahmadi A. General psychology. Jakarta: Rineka Cipta; 2009.

[39] Wijayanti, R., Sunarti, E., \& Krisnatuti, D. Peran dukungan sosial dan interaksi ibuanak dalam meningkatkan kesejahteraan subjektif remaja pada keluarga orang tua bekerja. Jurnal IImu Keluarga \& Konsumen. 2020;13:125-136.

[40] Rathomi, S., \& Nurhayati, E. Barriers to realizing open defecation free. Jurnal Integrasi Kesehatan \& Sains. Bandung: Universitas Islam Bandung. https://doi. org/10.29313/jiks. v1i1, 4325. 2019;1:68-73. 